\title{
Platforms and Tendencies for the Development of the Digital Economy in Russia
}

\author{
K.N. Ermolaev ${ }^{1}, O . V$. Trubetskaya $^{1}, K . V$. Shnyakin $^{1, *}$ and J.A. Pavlova ${ }^{1}$ \\ *Corresponding author: shnyakin_kv@mail.ru \\ ${ }^{1}$ Samara State University of Economics, Samara, Russia
}

\begin{abstract}
The relevance of this article is due to the fact that representations existing in science have not formed a common understanding of the essence, directions and implications of economy digitalization, therefore the purpose of the study is to substantiate and present the authors' understanding of the pattern of origin, the essence of the digital economy and its development. The category of the digital economy is considered in the unity of genetic, essential, structural and functional aspects. The authors substantiate the internal relationship of digitalization with the fourth industrial revolution and the introduction of digital technologies in all spheres of human activity. The scientific significance of the study is to disclose the content and main directions of Russia's systemic transition to a digital development model. The formulated methodological approach and the results obtained provide the possibility for further research on the essential features of the digital economy and the development of practical measures for its development, for the prevention of negative effects of digitalization, and for the development of measures for the institutional regulation of the systemic transition of the Russian economy to the digital development model.
\end{abstract}

Keywords: big data, digital economy, digitalization, fourth industrial revolution, information society, platform economy.

\section{Introduction}

The issue of economy digitalization is one of the most discussed in the modern economic literature. The authors join K. Schwab's opinion, who asserts that digitalization is a natural manifestation and content of the fourth industrial revolution, which blurs the lines between the physical, biological and digital reality to solve fundamentally new problems [1]. This revolution means that digital technologies, which have emerged from the Internet and mobile telecommunications, began to actively penetrate into all spheres of human activity. As a result, a new type of the economy emerges. This type functions on the basis of fundamentally new laws, when digitalization radically transforms the entire economic system while collecting, analyzing, storing and transmitting data. The authors believe that this position considers digitalization as the essential feature and the driving force of Kondratiev's new large cycle, reflecting the transition of humanity to the post-carbon era, when digital technologies in combination with new energy sources allow changing the functioning of the economy and its efficiency [2]. According to the authors, the understanding of the nature of digitalization opens up the possibility for humanity to solve two global problems on its basis: overcoming the financial turbulence of the modern global economy and preventing a global environmental catastrophe.

\section{Problem Statement}

The result of the development of modern information society is the formation of such an inevitable phase as the digital economy. Early studies on the theory and methodology of the digital economy are mainly focused on the analysis of the cost of information, the features of competitive behavior in the digital era and the solution of interconnection problems [3, 4]. From the point of view of modern understanding, the digital economy is a system of economic relations in which data is a key factor in the economic development in a digital form. This is "data economy" and "digital platforms economy", in which the use of modern digital technologies for creating, transmitting, storing and protecting data, when it is analyzed and used for decision-making, is of paramount importance. And since data transmission in the digital economy is one of the key aspects, the research of scientists concerned the issues of network neutrality [5, 6], problems of the ratio of openness of the digital economy, the control in the information space [7] and the features of digital platforms [8]. It is not a separate industry, it is a way of life, a new basis for the economic development of all aspects of the life of society and the individual.

\section{Research Questions}

Since the development of the digital economy in Russia started only after the adoption of a corresponding national program by the Government of the Russian Federation, the main issues of this study will be:

- Basic ideas and directions for the development of the digital economy;

- Implications of economy digitalization for society as a whole. 


\section{Purpose of the Study}

The purpose of the study is to quantify the digital sector in Russia based on the analysis of international indices of the development of the digital economy, to characterize the main areas of digitalization, as well as to assess the socioeconomic consequences of Russia's transition to digital.

\section{Research Methods}

In studying the problem, the authors used a methodological approach based on the application of materialistic dialectics to the analysis of the digital economy. It was characterized in the unity of genetic, essential, structural and functional aspects, which allowed explaining the reasons for its occurrence, formulating the essential features, identifying the basic tendencies for its development and analyzing the consequences.

Considering the genesis of the digital economy as the main component of the fourth industrial revolution made it possible to analyze its relationship with the development of information technologies, in which the use of the Internet and mobile telecommunications in all sectors of the economy has become objectively necessary. The pattern of the genesis of the digital economy as the material content of Kondratiev's new large cycle suggests that it is becoming a driver for the development of productive forces and requires a qualitatively new system of organizing economic relations, including issues of institutional regulation.

The genesis analysis allows considering the essential features of the digital economy as the data economy and digital platforms in which the acquisition, storage, transmission, and analysis of data takes a priority place. Material content and the basis of digitalization are separate tendencies for the development of information technologies, which in unity reflect qualitative differences of the information economy from the previous stage of its development.

The structural and functional analysis allowed revealing the main tendencies for the transition of the economy to the digital development model. The study of each of the five areas of the digital economy revealed patterns, contradictions and made hypothetical assumptions about the effects of economy digitalization.

\section{Findings}

Economy digitalization means a wide penetration of information and communication technologies into the activities of business and their automation, the emergence of new opportunities for providing services to the population through the Internet, the extensive development of mobile communications and conventional technologies. This is a new generation of the technological economy.

At the end of August 2018, the Ministry of Digital Development, Communications and Mass Communications submitted a draft national program "Digital Economy of the Russian Federation" to the government for approval. It defined goals and objectives within the framework of five basic directions: regulation, personnel and education, formation of research competencies and technical reserves, information infrastructure and information security. According to international data for 2016-2018, Russia occupied various positions among the countries in terms of the development of the digital economy. The grouping of data is shown in Table 1.

Table 1. Russia in international indices of the development of the digital economy

\begin{tabular}{|c|c|c|c|c|c|c|c|}
\hline \multicolumn{3}{|c|}{ ICT Development Index 2017} & \multicolumn{3}{|c|}{$\begin{array}{c}\text { E-Government Development } \\
\text { Index -(EGDI) }\end{array}$} & \multicolumn{2}{|c|}{$\begin{array}{c}\text { Networked Readiness } \\
\text { Index }\end{array}$} \\
\hline Country & 2017 & 2016 & Country & 2018 & 2016 & Country & 2016 \\
\hline 1. Iceland (2) & 8,98 & 8,78 & 1. Denmark (9) & 0,915 & 0,8510 & 1. Singapore & 6,0 \\
\hline $\begin{array}{l}\text { 2. The Republic } \\
\text { of Korea (1) }\end{array}$ & 8,85 & 8,80 & 2. Australia (2) & 0,9053 & 0,9143 & 2. Finland & 6,0 \\
\hline $\begin{array}{l}\text { 3. Switzerland } \\
\text { (4) }\end{array}$ & 8,74 & 8,66 & $\begin{array}{l}\text { 3. The Republic } \\
\text { of Korea (3) }\end{array}$ & 0,901 & 0,8915 & 3. Sweden & 5,8 \\
\hline 4. Denmark (3) & 8,71 & 8,68 & $\begin{array}{l}\text { 4. Great Britain } \\
\text { (1) }\end{array}$ & 0,8999 & 0,9193 & 4. Norway & 5,8 \\
\hline $\begin{array}{l}\text { 5.Great Britain } \\
\text { (5) }\end{array}$ & 8,65 & 8,53 & 5. Sweden (6) & 0,8882 & 0,8704 & 5. USA & 5,8 \\
\hline .. & & $\ldots$ & $\ldots$ & .. & & & \\
\hline 45. Russia (43) & 7,07 & 6,91 & 32.Russia (35) & 0,7969 & 0,7215 & 41. Russia & 4,5 \\
\hline
\end{tabular}

Source: compiled by the authors based on Analytical statement. Measuring the Information Society Report Executive summary (2017) [9]; Analytical statement. United Nations E-government Survey (2018) [10]; Analytical statement. The Global Information Technology Report (2016) [11]

The E-Government Development Index is a comprehensive indicator that assesses the readiness and capabilities of national government structures in the use of information and communication technologies (ICT) to provide public services to citizens. And Denmark, Korea, Great Britain are among the first. In particular, Denmark has managed to make a big breakthrough, rising from the 9 th to 1 st place in 2 years. Russia is obviously far from the top ten, but for the 
period under review it has risen from the 35 th position to the 32 nd in ratings. And, indeed, the access to e-government services is becoming easier.

Using the Network Readiness Index, factors, policies and institutions that allow a country to fully exploit the benefits of information and communication technologies (ICT) to increase the competitiveness and well-being are assessed. Remarkably, regarding the review of the previous indices, the Scandinavian Peninsula countries are in the top five, losing only to Singapore. Even the United States takes only the 5th place. Russia on this indicator is on the 41st place of the rating, which is connected, apparently, with the existing uneven penetration of the Internet into certain regions of Russia, mobile communications and networks, as well as the low availability of modern technologies for Russian society.

The strategy for the transition to the digital economy, outlined by the President of the Russian Federation and the Government of the Russian Federation, includes a complex set of transformations that is unprecedented in scale, significance and impact on the life of the country and the individual citizen. As noted above, Russia's systemic transition to the digital development model includes five main tendencies.

The first is the use of aforementioned technologies to create the infrastructure based on the mobile Internet and the ubiquitous distribution of fiber optic in the country.

In December 2018, the International Telecommunication Union (ITU) presented a report in which it reported that 3.9 billion people go online or $51.2 \%$ of the world's population [12]. The ranking of countries by the number of Internet users of the total population for 2018 will be presented in Table 2.

Table 2. The proportion of Internet users

\begin{tabular}{|l|c|c|c|}
\hline \multicolumn{1}{|c|}{ Country } & Population & Users & $\begin{array}{c}\text { \% of the } \\
\text { population }\end{array}$ \\
\hline 1. Norway & 5295619 & 5044737 & 96,81 \\
\hline 2. Denmark & 5806015 & 5461026 & 96,33 \\
\hline 3. Falkland Islands & 2931 & 2875 & 95,84 \\
\hline 4. Iceland & 332529 & 293465 & 95 \\
\hline 5. Great Britain & 66040229 & 62091419 & 94,8 \\
\hline .. & & $\ldots$ & $\ldots$ \\
\hline 43. Russia & 146880432 & 109552842 & 76,4 \\
\hline
\end{tabular}

Source: compiled by the authors based on Analytical statement. Measuring the Information Society Report Executive summary (2018) [12]

The percentage of Internet users' coverage indicates the need for the information infrastructure development, as a priority tendency in digitalization of the Russian economy.It is very important to form an appropriate regulatory framework, the adoption of more than 50 legislative acts in 10 areas of the development. Regulations on digital financial assets, digital transactions, electronic guarantees and digital pledges, electronic workbooks, electronic means of trust (identification of subjects and objects of the transaction, visualization of digital signatures), decentralized certificates of rights and number of others are to be introduced.

The third tendency is the creation of the technological groundwork and digital platforms serving digital data operations. It is necessary to create four base platforms. On the basis of the first one, a permanent electronic profile will be created for citizens, a kind of electronic passport containing all the necessary information to ensure its identification with the use of biometric data throughout the life cycle. In addition, the so-called "digital highway" will be created, providing a targeted and uniform movement of the entire set of collected data for the use in the interagency cooperation. The third platform is the integration of information from 5,000 websites of various government agencies to create a single "state showcase" on a single portal. The fourth platform should be a single geographic infrastructure for the digital interaction within the EAEU. The main purpose of created platforms is not only digitalization of existing processes, but primarily the formulation of fundamental new tasks that cannot be solved without the latest technologies for collecting, storing, processing and transmitting large amounts of unstructured data and developing effective solutions in real time.

The fourth tendency of digitalization is the formation of an adequate human potential. This implies the redistribution of released workers to other economic sectors, the emergence of new professions, the need to reform the entire system of education, training and retraining of personnel with the aim of forming basic qualifications and individual competencies that meet the needs of the digital economy.

The fifth tendency of digitalization is to ensure information security. The inevitable consequences of digitalization are hacker attacks, which have been subjected to information systems of organizations in various fields of activity, including government and government structures. Another aspect of this problem is the increasing use of social networks for political destabilization, protests, and various "color revolutions".

In the updated status, the program included six federal projects: regulation of the digital environment; frames for the digital economy; digital technologies and projects; information infrastructure; information security and digital state [13]. The ratio of the planned costs will be presented in the diagram. 


\section{information infrastructure digital government \\ staff for the digital economy $n$ digital technologies \\ information security $\quad$ regulation}

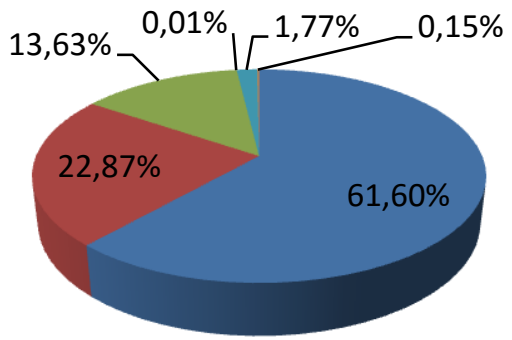

Figure 1. The ratio of costs in the areas of digitalization of the Russian economy

(Source: compiled by the authors based on [14])

In total, all listed projects will require funding in the amount of 1.2 trillion rubles. In this case, the most expensive will be the federal project "Information Infrastructure", which will require 627.9 billion rubles [14]. The process of economy digitalization leads to serious consequences. A number of economists believe that the transition to the digital economy is considered as a way to reduce production costs $[15,16]$. But digitalization processes radically change the underlying fundamentals of market functioning. There is a gradual digitalization of the market infrastructure through the launch of satellites, covering the whole world with communication, labeling of goods, allowing optimizing their logistics. This primarily concerns the functioning of the retail and especially the consumer goods market, as well as the media market. The share of digital sales of ordinary goods is growing, digital banks appear (Tinkov Bank, Alfa Bank and, to a certain extent, Sberbank) [17]. Thanks to digitalization, the process of transforming real markets - commodity markets - into financial ones is becoming more and more rapid. Self-digitalization of individual markets leads to the reduction in costs, to the enhanced competitiveness. Digitalization creates opportunities for transforming a part of the shadow market into the civilized one. For example, it allows you to pay taxes by the cell phone for so-called freelancers through the online office, i.e. through the application that will interact with the FTS on the calculation of taxes and automatic payment through the binding of the card to the phone number.

One of the negative consequences of digitalization was the emergence of a new type of monopoly - monopoly on information. This is due to a completely new phenomenon - a "platform economy", in which hubs dominate and gain an increasing share of value in the value chain of goods. They crush individual markets and also monopolize access of suppliers to consumers. The platform economy is a long-term trend, within which the economic and ethical problem of preserving the viability of traditional (non-digital) business arises, as indicated by Marco Iansiti and Karim Lakhani in the article "Economic Platform" [18]. It is also possible to single out a number of works devoted to the possible abuse in the field of the digital economy $[19,20]$.

Economy digitalization can lead to significant long-term socio-economic consequences. Hypothetically, we can assume that it will lead to a new quality of the interaction between virtual and physical systems, which will create a unit of value based on much lower resource costs. The development of Internet technologies and the elimination of a number of intermediaries will lead to a significant reduction in transaction costs and make more efficient the entire system of specification, circulation and protection of property rights. There may be significant changes in business organization models. Traditional barter can give way to a collective access to goods and services through digital networks, and competition and profit maximization can be replaced by the network interaction based on harmonization of interests.

\section{Conclusion}

Thus, Russia does not occupy a leading position in the world ratings of the development of digital space yet. The reasons for this are imperfections of the legislative base, the low availability of the latest ICT technologies for the population of the country, the uneven coverage of regions by mobile communication networks, etc.

For the full transition of the Russian Federation to digital it is necessary to create an appropriate infrastructure based on the ubiquitous distribution of fiber optic communications, the creation of digital platforms that will allow you to work effectively with data from citizens, government agencies, a unified geo-infrastructure, and information security. It should be remembered that economy digitalization leads not only to positive, but also to negative consequences, which can be eliminated through a balanced and rational state economic policy, drawing on the experience of leading countries in this area. 


\section{References}

1 K. Schwab, The fourth industrial revolution. Moscow: Izdatelstvo "E" (2018). [in Rus.].

2 R. Fux, Green revolution: economic growth without environmental damage. Moscow: Alpina non-fiction (2016). [in Rus.].

3 B. Caillaud, B. Jullien, Chicken \& egg: Competition among intermediation service providers. The RAND Journal of Economics, 34(2), 309-328. DOI: 10.2307/1593720 (2003).

4 J.K. MacKie-Mason, H. Varian, Economic FAQs about the internet. Journal of Economic Perspectives, 8(3), 75-96. DOI 10.1257/jep.8.3.75 (1994).

5 J.P. Choi, D.-S. Jeon, B.-C. Kim, Net neutrality, business models, and internet interconnection. American Economic Journal: Microeconomics, 7(3), 104-141. DOI: 10.1257/mic.20130162 (2015).

6 N. Economides, B.E. Hermalin, The economics of network neutrality. The RAND Journal of Economics, 43(4), 602-629. URL: http://www.stern.nyu.edu/networks/Economides-Hermalin_Economics_of_Network_Neutrality.pdf (2012).

7 S. Greenstein, M. Peitz, T. Valletti, Net neutrality: A fast lane to understanding the trade-offs. Journal of Economic Perspectives, 30(2), 127-150. DOI 10.3386/w21950 (2016).

8 A.Fradkin, E. Grewal, D. Holtz, The determinants of online review informativeness: Evidence from field experiments on airbnb. Working Paper. URL: https://papers.ssrn.com/sol3/papers.cfm?abstract_id=2939064 (2018).

9 Analytical statement. Measuring the Information Society Report Executive summary. Retrieved from http://www.itu.int/en/ITU-D/Statistics/Pages/publications/mis2017.aspx Accessed: 30.11 .2018 (2017).

10 Analytical statement. United Nations E-government Survey. Gearing e-government to support transformation towards sustainable and resilient societies. Retrieved from https://publicadministration.un.org/egovkb/enus/Reports/UN-E-Government-Survey-2018 Accessed: 30.11 .2018 (2018).

11 Analytical statement. The Global Information Technology Report. Innovating in the Digital Economy. Retrieved from http://www3.weforum.org/docs/GITR2016/GITR_2016_full\%20report final.pdf Accessed: 30.11 .2018 (2016).

12 Analytical statement. Measuring the Information Society Report Executive summary. Retrieved from https://www.itu.int/en/ITU-D/Statistics/Pages/default.aspx Accessed: 02.12.2018 (2018).

13 Program "Cifrovaya economika Rossiyskoy Federacii" from 28.07.2016 N 1632-r. URL: http://static.government.ru/media/files/9gFM4FHj4PsB79I5v7yLVuPgu4bvR7M0.pdf. $\quad$ Accessed: 15.11 .2018 (2016). [in Rus].

14 V. Kodachigov, E. Bazanova, P. Kantyshev, The budget of the digital economy was estimated at 1.2 trillion rubles. Vedomosti, 152 (2018). [in Rus.].

15 G. Ellison, S.F. Ellison, Lessons about markets from the internet. Journal of Economic Perspectives, 19(2), 139158. DOI: $10.1257 / 0895330054048632$ (2005).

16 M.D. Smith, J. Bailey, E. Brynjolfsson, Understanding digital markets: review and assessment. MIT Sloan school of management working paper, 4211-01, 99-136. URL: https://papers.ssrn.com/sol3/papers.cfm?abstract_id=290326 (2001).

17 V. Kodachigov, Digital economy flies into space. Vedomosti, 220 (2017). [in Rus.].

18 M. Iansiti, K.R. Lakhani, The economy of platforms. Harvard Business Review Russia. URL: https://hbrrussia.ru/biznes-i-obshchestvo/fenomeny/a23621 (2017). [in Rus.].

19 C.V. Amasiatu, M.H. Shah, First party fraud: A review of the forms and motives of fraudulent consumer behaviors in e-tailing. International Journal of Retail \& Distribution Management 42(9), 805-817. URL: https://www.emeraldinsight.com/doi/abs/10.1108/IJRDM-05-2013-0112 (2014).

20 S. Dobson, A. Sukumar, L. Tipi, Dark matters: The institutional entrepreneurship of illicit and illegal cyberspace. Contemporary Issues in Entrepreneurship Research, 5, 179-201. DOI: 10.1108/S2040-724620150000005014 (2015). 